\title{
THE DNIEPER-DON FOREST-STEPPE AS AN ETHNO-CONTACT ZONE: RUSSIA, THE POLISH-LITHUANIAN COMMONWEALTH, AND THE CRIMEAN KHANATE*
}

A. I. Papkov

Belgorod National

Research University
А. И. Папков

Белгородский государственный национальный исследовательский

университет

Abstract. This article deals with the process of Russian territorial expansion to the south in the sixteenth century. It analyzes the conflict between Russia, the Polish-Lithuanian Commonwealth, and the Crimean Khanate in the struggle for domination of the Dnieper-Don forest-steppe. The author concludes that this competition resulted not only in the annexation of certain territories by these countries, but also in their gaining valuable experience in interacting with interstate and borderland populations. At the same time, local inhabitants of Russia and the Polish-Lithuanian Commonwealth in these contested territories had to develop effective mechanisms of coexistence.

Keywords: Russian Tsardom, South of Russia, Dnieper-Don forest-steppe, Crimean Khanate, Polish-Lithuanian Commonwealth, Ukrainians, frontier, borderland.

E-mail: papkov[at]bsu.edu.ru

Copyright: (C) 2014 Papkov. This is an open-access article distributed under the terms of the Creative Commons Attribution License (CC BY 4.0), which permits unrestricted use, distribution, and reproduction in any medium, provided the original author and source are credited.

Удк 94(47).04

\section{ДНЕПРО-ДОНСКАЯ АЕСОСТЕПЬ КАК ЭТНОКОНТАКТНАЯ ЗОНА: РОССИЯ, РЕЧЬ ПОСПОИИТАЯ И КРЫМСКОЕ ХАНСТВО}

Аннотаиия. В статье рассматривается процесс расширения государственной территории России в южном направлении, происходивший в XVI в. Анализируются противоречия, возникавшие между Россией, Речью Посполитой и Крымским ханством в результате напряженной конкурентной борьбы за господство в Днепро-Донской месостепи. Автор приходит к выводу о том, что результатом противоречий и соперниче-

\footnotetext{
* The study was supported by the Ministry of Education and Science of the Russian Federation, project 14.B37.21.0457.
} 
ства стало не только закрепление конкретных земель за отдемьными государствами, но и получение ценного опыта как межгосударственного взаимодействия, так и пограничного взаимодействия насемения, который позволим в дальнейшем найти эффективные механизмы сосуществования подданных России и Речи Посполитой на спорных территориях.

Ключевъе слова: Российское царство, Юг России, Днепро-Донская месостепь, Крымское ханство, Речь Посполитая, украинцы, порубежье.

The formation of an integrated Russian state was completed in 1521 with the incorporation of Riazan'; a new stage of development began. Russian territory now bordered the sparsely populated steppe areas. Once Riazan' was joined to Moscow, the defensive line along the Oka river closed and the Prince of All Rus' exercised the power to oversee the defense of the southern frontier at his own initiative and discretion (Liubavskii 1996, 252). All Russian lands not included in the Grand Duchy of Lithuania belonged to the principality. From the viewpoint of the ruling elite, further consolidation of Russia's international position depended on the territorial expansion of the state. The existence of powerful and hostile neighbors required Russia to combine its political borders with natural boundaries formed by mountain chains, swamps, big rivers, lakes, and seacoasts, an advantageous strategy for organizing of defense of territories from armed attacks. Russian expansion during and after the sixteenth century occurred in multiple directions, but the most important was to the south. Because of the geographical peculiarities of the region (forest-steppe and steppe), the southern border was relatively unstable in comparison with Russia's western border, where the existence of multiple natural barriers promoted strong defense.

To help clarify this discussion, it is useful to define some terms employed in this article. The territory under study is the forest-steppe bordering the Polish-Lithuanian Commonwealth where Eastern Slavs lived. The Russian documents (from the end of the sixteenth through the first half of the seventeenth century) describe the lands as "Field" (Pole), which is an approximate synonym of 'steppe', or "Field's frontier" (Pol'skaia ukraina). ${ }^{1}$ Conrad Bussow, a German witness to the Time of Troubles, began to apply the term "wild Field" ("wilde Feld" / "dikoe pole") in regard to this area (Bussow 1961 [1831], 94), and, as a result, a number of historians (e.g. Cherepnin 1960, 415) have mistakenly used the term as a geographic designation. Some scholars, however, have sufficiently proven the unsuitabil-

\footnotetext{
${ }^{1}$ Russian sources also designated the steppe areas situated between the Golden Horde territories and Russian lands as "Field." See Khoroshkevich 2001b, 63 (note 3).
} 
ity of the given term for these lands. In this period "wild field" simply meant virgin soil (Zagorovskii 1972, 37-38). Accordingly the Russian documents identify many towns in the Dnieper-Don forest-steppe as "Field's towns" or "towns in the Field," in contrast to Severskie and Riazan' towns, which were dubbed "towns from the Field."

Voevods ruled the towns with full military and administrative powers. Those from towns "in the Field" frequently came in contact with the administration of southern territories of the Polish-Lithuanian Commonwealth. Every year from early spring to late autumn, Russian "storozh" were established. These were observation points typically manned by two to six service men. At the same time, minor cavalry military detachments (stanitsy) of ten to twenty men were sent to the steppe to patrol the frontier.

The problem of applying such terms as "Ukraine" and "Ukrainian" deserves special mention. This is connected to the still unresolved question of Ukrainians ' (in the modern understanding of this word) origins, an issue further complicated by the influence of various ideological clichés. ${ }^{2}$ For a long time, Russian historiography espoused the idea that the Ukrainian people had fully formed by the late fourteenth century (Mavrodin 1978, 146; Bromlei 1988, 472). Other scholarship dated the formation of the Ukrainian nation only to the sixteenth or early seventeenth centuries, noting that "Ukraine" as the name for the ethnic territory had been used since the end of the sixteenth century (Kondufor 1990, 44-45). This reflects the complexity of Ukrainian ethnic history, given that the people employed a variety of ways of naming themselves (ethnonyms) and their territory. In scientific literature there are two basic viewpoints concerning the origin of the Ukrainian nation. The first is connected with the so-called "theory of continuous development of nations." According to this theory, the direct ancestors of the Ukrainians were Neolithic people who lived on the territory of modern Ukraine and who evolved first to Neuri, then to Antes, further to Rus ' in the period of Kievan Rus', and at last to Ukrainians. The second one is represented by the so-called "academic viewpoint," according to which the formation of the Ukrainians began in the period of feudal disunity of the Old Russian State (the twelfth and thirteenth centuries) and ended in the fourteenth and fifteenth centuries. Both theories are debatable, but the appearance of the term "Ukraina" in the Hypatian Codex of 1187 adds weight to the latter theory (Polishchuk 2000, 5-19).

B. N. Floria notes that starting with the end of the fourteenth century, one can speak about the different historic destinies of the East Slavs in the framework of new multiethnic states: the Grand Duchy of Lithuania and the Polish Kingdom on one hand, and the developing Russian state on the other. He marks the last quarter of the fourteenth century as the period when the consciousness of differences resulted in changes in the char-

\footnotetext{
${ }^{2}$ For more details see Gorizontov 2002; Sysyn 1986.
} 
acter of East Slavs' ethnic self-consciousness on the territory of this state (Miller 1997, 12-16; Floria 1997, 92-94). Floria further argues, "the process of ethnic differentiation between the East Slavs in the PolishLithuanian Commonwealth and Russia from the end of the sixteenth to the early seventeenth century was rather deep, but was far from its final completion; the conception of East Slavs united as a singular ethnic community continued to occupy an important place" (Miller 1997, 19). In addition, Floria characterizes the process of ethnic development of the East Slavs in the fifteenth through seventeenth centuries more definitely: "Starting with the end of the fourteenth century, the paths of historic development of the East Slavs were clearly different. Those who were in the Grand Duchy of Lithuania and the Polish Kingdom had one path of development; those who were united within the Russian state had another. Although many common traditions, customs, and religious beliefs remained, at the same time, many social, and later cultural, differences appeared during the fifteenth and sixteenth centuries. It appears to me that the objective result of this was the fact that by approximately the seventeenth century the East Slavs on the both sides of the border began to consider each other as closely related, but at the same time different, special peoples" (Gorizontov 2002, 8-9).

In the first half of the seventeenth century, the Orthodox population of Poland identified as "Russian" (russkit), but the word "Ukrainian" (ukrainets) denoted an inhabitant of the outlying districts. However, Russians living in Russia, including its southern borderlands, were strictly differentiated from Russians living in Poland, and were identified as "rossiiskie" (Gumilev 1992, 244 (note); Rusyna 1998, 276-277). There is another view of the matter, according to which the ethnonym "ukrainets" was used along with the Old Russian designations "rus'kl" and "russkii" in the fifteenth and sixteenth centuries (Polishchuk 2000, 20). Nevertheless it is rather difficult to define what is hidden behind the first term.

It bears mention that in the domestic historical literature the term "Ukraina" was firmly established as demarcating the left bank of the Dnieper River and "ukraintsy" as denoting the population of these territories in the sixteenth and seventeenth centuries. ${ }^{3}$ The phrase "ukrainskoe pogranich'e" figured in official documents of the Polish-Lithuanian Commonwealth, for example in the edict of Sigismund III in 1590 (Kulish 1888, 52-53). G. Beauplan, a French engineer who served in the PolishLithuanian Commonwealth, used the term "Ukraina" as a geographic descriptor in his work, published in Paris in 1651 (Beauplan 1832 [1651]). Recall that using such macrotoponyms as "Lesser Rus" and "Little Rus" to refer to the territory of contemporary Ukraine in the sixteenth and sev-

\footnotetext{
3 See, for example, Tikhomirov 1962, 418-419; Alekberli 1961, 37; Zimin 1972, 164, 311; Floria 1978, 17 and subsequent pages; Pashuto, Floria, Khoroshkevich 1982, 66, 229; Stanislavskii 1990, 7-8; Pokhlebkin 1992, 183; Pokhlebkin 1995, 392, 439-446; Sakharov 1999, 230, 277-298.
} 
enteenth centuries is not appropriate (Rusyna 276). Employing the term "Little Rus" in literature in the late sixteenth century, as well as in the sphere of ecclesiastical relations, is not a sufficient explanation for this denotation of Ukrainian ethnic territory (Miller 1997, 16-17). This term may be reasonably used only from the middle of the seventeenth century. At that time, the phrase "Little Rus" was included in the title of Tsar Aleksei Mikhailovich and in official language. It is worth mentioning that authors of summary works (e.g. Polishchuk 2000, 19) and foreign scientists ${ }^{4}$ both consider the latter approach acceptable. These and other factors laid the foundation for continued use of the term "Ukraine" by modern scholars to refer to the left bank of the Dnieper River and "Ukrainians" to refer to the Slavic people on this territory. ${ }^{5}$ At the same time, specialists of the East Slavs' development in the seventeenth century feel compelled to use also such terms as "Ukrainian-Belorussian influence," while admitting the necessity of notional set sorting and the absence of comparable terms in historical documents (Gorizontov 2002, 13-17).

M. K. Liubavskii notes that after the Truce of Deulino in 1618 the term "Ukraine" was also applied to the portion of the Chernigov territory that Poland seized from Russia; in 1635 Chernigov voevodship was formed (Liubavskii 1996, 335). In sum, it is appropriate to use the term "Ukraine" for the left bank of the Dnieper River in the sixteenth and seventeenth centuries.

Inhabitants of the Ukrainian lands of the Polish-Lithuanian Commonwealth were considered "cherkasy" or "Lithuanian people" in the Russian sources of the late sixteenth and early seventeenth century. In some documents, these terms are synonyms; in others they have different meanings. In the latter case, the Ukrainian Cossacks were labelled "Cherkasy" and all inhabitants of left-bank Ukraine in the Grand Duchy of Lithuania were considered "Lithuanian people." Zaporozhian Cossacks were frequently singled out from other Ukrainian Cossacks as "Zaporozhian Cherkasy." The appearance of the term "Cherkasy" is connected with the town Cherkasy, which became the center of the Ukrainian Cossacks in the latter half of the sixteenth century. The evolution of this term deserves further explanation. It first appeared as the term for Ukrainian Cossacks in the sixteenth century and by the mid-seventeenth century all inhabitants of Ukraine were considered "Cherkasy" in all official Russian documents. This generalization holds true for the borderlands of interest in this article through at least the mid-seventeenth century. It is significant that in eighteenth-century censuses (revizii), descendants of Ukrainian migrants from the early seventeenth century identified themselves as "Cherkassian subjects," but those of migrants after 1654 identified as "Little Russian

\footnotetext{
${ }^{4}$ See, for example, Bushkovitch 1986, 356; Sysyn 1985, 136; Sysyn 1986, 101-102, 105.

${ }^{5}$ See Miller 1997, 43, 51, 61, 126; Skrynnikov 1997, 443; Solodkin 1999, 37-41; Smolij and Stepanov 1999, 41-61.
} 
(malorossiiane) subjects." There must be some connection between terms used in documents and the state's interest in settling the borderlands with service class people rather than peasants until the incorporation of "Little Rus" into Russia in the mid-seventeenth century. "Cherkasy," who did not pledge allegiance to the Russian Tsar and plundered "in the Field" (na Pole), were usually identified as "vorovskie" ("thieves").

Floria has noticed that in early seventeenth-century Moscow documents the East Slavs of the Polish-Lithuanian Commonwealth were denoted as "Cherkasy" and "belorustsy" (Floria 2002, 38). A search of the sources suggests that the latter was used more rarely and as a rule in the confessional context. Typically, Orthodox priests from the PolishLithuanian Commonwealth (i.e. Orthodox subjects of Polish crown) were referred to by this term as opposed to Catholics or Uniates, as well as Orthodox believers who lived in Russia. Naturalized "Belorustsy" were sent to Russian monasteries for "faith correction," along with those who had been under Tatar captivity and those who were preparing to join the Orthodox faith. Thus it is correct to use the term "Cherkasy" for inhabitants of Ukrainian lands included in the Polish-Lithuanian Commonwealth, especially because it was used in official Russian documents and became the self-designation of migrants from Ukraine to Russia.

The situation on Russia's frontiers was complicated by constant conflicts with aggressive neighbors: the Crimean Khanate and later the PolishLithuanian Commonwealth (e.g. Vodarskii 1973, 22-23). For a long time, the steppe was a source of constant threat for the Slavs. Tatar detachments roamed these lands, raiding the Slavs and enslaving captured inhabitants. This was not the territory's sole problem: all three states-the Tsardom of Russia (since 1547), the Polish-Lithuanian Commonwealth, and the Crimean Khanate-laid claim to the Dnieper-Don forest-steppe adjacent to the southern Russian borderlands.

The fact that many outstanding historians have addressed this problem in different contexts proves its great importance. M. K. Liubavskii pays special attention to the issue in his chapter, "conflict between the Tsardom of Muscovy and the Crimean Tatars, and the settlement of the black soil steppe" (Liubavskii 1996, 285-311). Liubavskii describes the struggle between Russian settlers and the Crimean Tatars. Although he mentions the migration of Ukrainians to the southern Russian borderlands, he does not analyze this process in detail (Liubavskii 1918, 10-19). Describing the regions of the Russian state on the eve of the Time of Troubles, S. F. Platonov sketched out the geographic characteristics of "the Field," and noted the dominance of governmental over grassroots colonization in the upper portions of the rivers Seim, Severski Donets, and Oskol during the late sixteenth century (Platonov 1994, 55-62).

I. D. Beliaev crafted the first professional work devoted to the Dnieper-Don forest-steppe in the sixteenth century (Beliaev 1846). Late ninteenth-century Ukrainian historians D. I. Bagalei and I. N. Miklashevskii 
carried out significant research about this territory (Bagalei 1887; Miklashevskii 1894). The two men devoted their works primarily to the economic aspects of development and settlement of "the Field" in the seventeenth century. In his articles, Bagalei describes the collision of two colonization streams: "Great Russian" and "Little Russian." He notes that he examined each stream separately and did not offer a comparison (Bagalei 1886; 1913).

The tradition of regional research in the light of economic development and settlement, and against the background of constant struggle with the Crimean Tatars, was continued by Soviet scholars (Protorchina 1948; Zagorovskii 1991). A. A. Novosel'skii authored the foundational work concerning the history of the southern frontier (Novosel'skii 1948).

Authors of works on international relations pay little to no attention to the problem of interaction between Russia, the Polish-Lithuanian Commonwealth, and the Crimean Khanate in the Dnieper-Don forest-steppe. ${ }^{6}$ While scholarship exists regarding the problems of integration of Russian expatriates in the Polish-Lithuanian Commonwealth, these works concern only the lives of elites and do not address the borderlands (Erusalimskii 2011, 7-54).

In short, the issue of the Dnieper-Don forest-steppe is insufficiently explored. Yet extant diplomatic correspondence and Russian edict records make possible an analysis of international relations on the territory of "the Field" in the late sixteenth century. Moreover, taking into consideration the achievements of modern historical scholarship, it makes sense to research the Dnieper-Don forest-steppe as an ethnic contact zone. Some scholarly literature makes mention of the controversial problem of the so-called "Big border," i.e. the border between European and non-European civilizations (Dashkevich 1989, 7-21). The term "Big border" most frequently refers to the ethno-contact zone between the Christian West and the pagan, and later Islamic, East. However, the phenomenon of a special frontier way of life was typical not only for this zone (Dashkevich 1989, 10). The Russian southern borderlands in the sixteenth century can also be characterized as a zone of special social conditions and of ethnic and social integration. This corresponds to Frederick Jackson Turner's frontier thesis (Vorob'eva 2012, 102), a concept used not only in foreign, but also Russian historiography. ${ }^{7}$ It is easy to notice that in Russian historiography, the concept of "frontier" has received the most attention in connection with the study of Siberian development. At the same time, a "mobile border" also characterized other directions of Russian territorial expansion, including to the

\footnotetext{
${ }^{6}$ See, for example, Floria 1978; Zaborovskii 1981, etc.

7 See, for example, Zamiatina 1998, 75-88; Ageev 2005; Rezun et al. 2002; Rezun 2005; Poberezhnikov 2009, 25-30; Poberezhnikov 2011, 191-203.
} 
south in the sixteenth and seventeenth centuries. ${ }^{8}$ Professor of Loyola University-Chicago Michael Khodarkovsky has demonstrated this fact in his published works on relations between Russia and the Steppe, with a focus on the southeastern frontier. In particular, he examines relations between Russia and the Golden Horde (and subsequently the Tatar states formed after its breakup) (Khodarkovsky 2002; 1999).

It should be noted that this field is currently undergoing a rethinking of the place of frontier territories in the social history of individual countries and regions. This has required a rejection of interpretations that label these lands as somehow peripheral, marginal, or unimportant. Instead, scholars note the substantial potential of frontiers (cultural, economic, and political), their unique functional ability to initiate integration, and the broad sphere of interaction that contributes the development of territories, including those far from the borderlands. Moreover, when researching this problem, the notion of "frontier territories" should not refer simply to a narrow strip on both sides of a state or administrative border. It is more productive to consider a much broader zone that could be considered "frontier." In this regard, a "border" is defined as a wide, transitional zone, borrowing from the term "ecotone" in the field of physical geography (Krylov 2012, 28). Still, the issue of ethno-contact formation and frontier zones is far from fully examined, even under these more productive methods of scholarly research (Podgrushnyi 2010; Gritsenko 2010).

Russian expansion into the Severskie lands, which earlier belonged to the Grand Duchy of Lithuania, led to a tangle of contradictory relations between these two states in the early sixteenth century. ${ }^{9}$ Beginning in 1507, the Grand Principality of Moscow experienced constant attacks from the Crimean Tatars. In the Dnieper-Don forest-steppe there were a lot of Tatar roads around dense woodlands and broad rivers. As a rule, the roads were laid according to watersheds. This was because in the spring, snow thawed earlier on higher ground on the steppe, this ground dried more quickly, and thus the grass, much needed for the Tatars' horses, grew faster. In the sixteenth century, Russia's sphere of interests in its southern borderlands was not economic, but strategic. During the entire sixteenth century, peasants developed the lands to the south of the Oka River. They considered this activity as a return to their own lands, which they had had

\footnotetext{
8 See, for example, Shaw 1983; Mizis and Kashchenko 2011; Zhukov, Kanishchev, Liamin 2012.

${ }_{9}$ As a result of the first Russian-Lithuanian war in the sixteenth century, the Prince of all Rus ' claimed almost all Chernogiv-Severskie lands, including towns and adjacent countryside in the given region, namely Chernigov, Putivl', Ryl'sk, and Novgorod-Severskii. An attempt by the Grand Duchy of Lithuania to reclaim the lost territories in 1507-1508 was not successful. According to the "Perpetual Peace" signed October 8, 1508, Lithuania recognized all the conquests of Ivan III. The situation remained static after the third (1512-1522) and the fourth (1534-1537) Russian-Lithuanian wars. (See: Pokhlebkin 1995, 363-379; Tikhomirov 1962, 18).
} 
to abandon because of the Mongol conquest of Rus'. ${ }^{10}$ Colonization poured over into conflict between the Tsardom of Russia, which considered itself the successor of Kievan Rus', and the Crimean Khanate, which considered itself the successor of the Golden Horde, though the latter did not proclaim this openly. ${ }^{11}$ The governmental strategy consisted of building new defensive lines and fortresses for the protection of peasants. Thus the colonization of the southern borderlands had a national and a governmental character. This is particularly important when one takes into consideration the fact that black earth was more fertile, but harder to plow with the traditional equipment used by Russian farmers, who were accustomed to the lighter grey forest soils. The turf of forest soils consists of a weak sod and a fragile structure, which is why the main agrotechnical demand for their tillage is moldering and mixing rather than undercutting and reversing (what a plow does); wooden plows are more suitable for this (Krasnov 1987, 195). Nevertheless, a simple wooden plow ('sokha) with two iron shares was the main agricultural implement not only in the forest center but also in the southern forest-steppe in the late sixteenth and early seventeenth centuries. This fact offers clear evidence of the predominance of military and strategic over economic (which would have preference later) motivating factors in southern steppe colonization. At the same time in the sixteenth century, according to foreigners' descriptions, there was clear understanding of the higher fertility of soils in Riazan' region as compared to the Russian heartland (Solov'ev 1993 [1901], 361).

The Dnieper-Don forest-steppe became a zone of intersecting interests for three powers: Russia, the Polish-Lithuanian Commonwealth, and the Crimean Khanate. Russia strove for the colonization of these territories as they provided some definite advantages. First, the settlement and development of these lands by service class people allowed Russia to form a new defensive line against Tatar raids. Second, any expansion to the southwest was advantageous for Russia as it made possible more effective resistance to Polish aspirations to the east. Further, the Kingdom of Poland and the Grand Duchy of Lithuania were traditional, long-time rivals of Russia. The high point of territorial expansion and growth in power by Russia's western enemies in the steppe region was the Union of Lublin, signed by the Kingdom of Poland and the Grand Duchy of Lithuania. This resulted in the foundation of a single state: the Polish-Lithuanian Commonwealth in 1569 (Fal'kovich 2011, 156). Moreover, beginning with the reign of Vasilii III, all grand princes of Moscow claimed possession of some part of lands belonging to the Polish-Lithuanian Commonwealth.

\footnotetext{
10 Concerning pre-Mongol settlements in the Dnieper-Don forest-steppe see, for example, D'iachenko 1998; Vinnikov and Kudriavtseva 1998; Tropin 1999.

11 See in more detail Novosel'skii 1948, 41; Khoroshkevich 1999; Khoroshkevich 2001a, 225-271.
} 
For its part, the Polish-Lithuanian Commonwealth tried to prevent further growth of Russia's power. No natural borders separated the two states; therefore they constantly opposed each other. It is interesting that both states cited history and the law in bolstering their claims to these territories, although none of these claims brought any fruits. Another factor then came the foreground: colonization. The state that succeeded in staking its claim to the disputed territories in both a military and economic sense would win the territorial controversy. It is remarkable that the colonization of the southern borderlands of Russia and the Polish-Lithuanian Commonwealth began nearly simultaneously in the last decades of the sixteenth century (Padalka 1914, 53).

Forest-steppe lands situated between the Dnieper and the Don were not permanent settlement areas for the Crimean Tatars. As nomads, the Tatars could not develop and consolidate ownership of the basin of the Severski Donets River and other tributaries of the Dnieper and the Don, but they considered these lands to be a part of the Crimean Khanate. Although they did not live there all year round, they used these territories as summer camping grounds. As a result, the Tatars tried to block the colonization of "the Field" by other states. During the late sixteenth century, this territory was akin to a buffer zone between Russia and the Crimean Khanate. This situation made the Khanate nearly invulnerable. In regard to the Russian campaign against the Crimean Khanate, the Russian army had to move forward along the waterless steppe with a bulky string of carts. The Khan had the ability to gather strength and attack enemies periodically with small detachments. The buffer zone was the convenient territory for the concentration of the Tatars before raids and also it made it easier to dodge pursuers.

The invasion of Crimean Khan Mehmed I Giray through "the Field" to Moscow in 1521 demonstrated Russia's need to review its policy concerning its southern borderlands. Over the next decade, Vasilii III continued to improve the defensive system in the southern borderlands, but he made no attempt to organize the defensive lines along the paths of Tatars' raids, "on the Field." In 1530-1540, there were two frontier lines in the Russian south. The main line ran along the Oka River to the south. The second was the line "from the Field," which included such towns as Tula, Odoev, Belev, Bobrik, Pronsk, Zaraisk, later Novgorod-Severskii, Putivl', Pochep, Karachev, and Mtsensk. The town of Riazan' (Pereiaslavl'-Riazanskii) was also included in this line, although the town was situated far from the main bank of the Oka River. By the mid-sixteenth century, the line "from the Field" received another name: "from Crimean ukraina." Both lines shared a common task. An analysis of official registries led V. I. Buganov to conclude that in Moscow, service "on the bank" and service "from the Field" were considered as a single, unified whole (Buganov 1980, 208-209). Brick fortresses were constructed in Zaraisk and Kolomna. After devastating raids by the Tatars on Riazan' lands in 1533 and 1535, the state de- 
cided to restore the town of Pronsk as fortification from the south to Pereiaslavl'-Riazanskii (Zagorovskii 1991, 76-79).

In the summer in 1541, Russian governmental reconnaissance "in the Field" began. On the orders of Prince I. F. Bel'skii, Gavrila Tolmach's troops were sent to survey Tatar roads. When the subsequent Tatar invasion was repelled, however, Russian reconnaissance activities in the Dnieper-Don forest-steppe petered out. From 1541 to 1546, the Crimean Tatars made repeated attacks on the Russian frontier (Zagorovskii 1991, 81-84). By the mid-sixteenth century, the Russian government was fully aware of the disadvantage of its geopolitical situation in this region. It initiated a southern strategy after the conquest of Kazan' in 1552. Gradual construction of fortresses began in frontier districts near "the Field" after this event. As a result of building such "towns against Field's Ukraine" as Mikhailov, Shatsk, Dedilov, Bolkhov, Riazhsk, Novosil', Orel, Epifan', Dankov, and others, the Russian government clashed with the Crimean Khanate over possession of "the Field" in 1555. By joint decision of the Tsar and the council of boyars, a detachment $(13,000$ people) under the command of I. V. Bolshoi Sheremetev was sent to the Crimean Khanate. The tactical aims of that campaign were not realized due to the Tatar invasion of Moscow, which ended with the Battle of Sud'bishchi on July 3, 1555. Nevertheless, the strategic aim - the demonstration of the increased power of the Russian state - was attained (Zagorovskii 1991, 115-121). In 1557, in addition to the traditional assembly of noble cavalry regiments at the Oka River, the voevod with service class people assembled deep into the Dnieper-Don forest-steppe, as far as the Bystraia Sosna and Seim Rivers. Thus a temporary front defensive line was established on the territory of "the Field." Interestingly, V. P. Zagorovskii has observed that the places where the Russian army assembled "in the Field" in 1557 became three new towns-Livny, Yelets, and Kursk (Zagorovskii 1991, 127-128). Still, the campaigns of the Russian army to the Bystraia Sosna and Seim Rivers did not lead to the immediate consolidation of the Russian Tsardom on this part of the Dnieper-Don forest-steppe; the concentration of the Russian army here was not regular.

The government of Ivan the Terrible attempted to win victory over the Tatars in 1559. That year, Russian detachments under the command of I. M. Veshniakov and D. F. Adashev attacked the Crimean Khanate from the lower Don and Dnieper. However, only a small number of detachments participated in this campaign; thus it was ineffective. Later in the period of 1560-1562, Russian foreign policy underwent gradual change: a western orientation began to predominate over a southern orientation. The Tatars took the initiative in the Dnieper-Don forest-steppe and neighboring regions. The Russian government likely concluded that it had insufficient power to hold the southern line. Such confrontation with the Crimean Khanate demanded the constant presence of a sizable military contingent on the bank of the Oka River irrespective of other campaigns elsewhere on 
the frontier (Novosel'ski 1948, 23). During the Livonian War, this was impossible. In July 1562, Crimean Khan Devlet-Giray attacked Mtsensk and Mtsensk districts (uezd). Detachments under the command of Divey-Murza and Mustafa-Aga ravaged Bolkhov and Belevsk districts. ${ }^{12}$

Following the establishment of the town of Donkov (1568), Russian construction of new towns in this region tapered off for at least the two subsequent decades. The general construction of the southern defensive lines changed and after 1569, the presence of military contingents on the banks of the Oka River became obligatory. The situation in 1570 exemplified the shifts in Russian policy concerning its southern borders. That year an attack by the Crimean Khan failed, but Russia had to mobilize all of its military might to repulse the invasion. Ivan IV personally led the regiments of the noble cavalry. He arrived together with his son Ivan from the Alexandrovsky Kremlin sloboda to Serpukhov. This is perhaps a clear moment when the unsatisfactory state of Russian reconnaissance in the DnieperDon forest-steppe was laid bare, and Russia had no choice but to recognize the need to reorganize sentry and stanitsa duties.

From 1571 the All-Russian sentry service began to function "in the Field," organized by the boyar M. I. Vorotynskii. Every year from early spring to deep autumn, Russian sentries and other detachments were stationed "in the Field." The border service at that time consisted of three elements: 1) Putivl' and Ryl'sk detachments along routes approved by Moscow; 2) sentries from towns in frontier districts in places also approved by Moscow, who watched the roads for possible Tatar invasion; and 3) AllRussian sentries situated "in the Field" who sent their own detachments in all directions. The first All-Russian observation point was situated at the confluence of the Balykleia and Vapa Rivers, the second on the left bank of the Don River above the mouth of the Khopior River, the third at the Oskol River near the mouth of the Ublia River, and the fourth at the Seim River near the mouth of the Khona River.

Beginning in 1573, the armed forces of frontier Russian towns united into the "ukrainnyi razriad" to prevent a Tatar incursion into Moscow. The second defensive line was represented by the "riverbank razriad" (at the Oka River), which consisted of noble cavalry. In 1575-1576, the position of some All-Russian observation points changed. As a result, the westernmost observation point moved from the Seim River bank to the Severski Donets River, the mouth of the Ud River. The devastation caused by the unfortunate Livonian War led to the reduction of All-Russian observation points "in the Field" from four down to two, including the point at the Severski Donets River. Only the observation points at the Oskol River near the mouth of the Ublia River and at the Don River remained, each with seventy people (Zagorovskii 1991, 156-187; Margolin 1948, 3-28). By this time,

12 See more detail in Zagorovskii 1991, 133-141. 
Russia made an official attempt to incorporate "the Field" into its territory. Voevod M. Tiufiakin and clerk M. Rzhevskii demarcated the southern border of the Russian state with special signs.

From the 1580s onward, Russia engaged in the construction of fortresses directly "in the Field," which served as footholds against the Crimean Khanate. In 1586 it founded Livny and Voronezh. As V. P. Zagorovskii has noted, the establishment of these towns was meant to block Tatar roads, as well as to keep the portion of "the Field" near the Don for Russia. This goal acquired greater urgency in connection with the appearance of Cherkasy in the Dnieper-Don forest-steppe.

In 1591 Crimean Khan Gazi II Giray attacked Moscow. This invasion largely failed, but it revealed weaknesses in the Russian defensive system along the southern border. The Crimean Tatars marched toward Moscow, circumventing Livny on the left and Voronezh on the right. In response, the town of Yelets was founded in 1592, followed shortly therafter by Belgorod and Oskol. It is worth noting that from 1596, voevods held responsibility for the garrisons of town fortifications. The town of Valuiki was likely founded in this manner. Tsarev-Borisov, built in the summer of 1599 at the confluence of the Severski Donets and the Oskol, represented Russia's furthest extension into "the Field." Remarkably, Russia intended its construction not only to solve the problems with the Crimean Khanate, but also to oust the Cherkasy from this region (Zagorovskii 1991, 224-226).

Russia accumulated much experience in its relations with the Crimean Khanate, and this helped to resolve problems related to the colonization of the Field's borderlands. In 1593 Crimean Khan Gazi II Giray received a letter on the Tsar's behalf; most likely Boris Godunov took part in its writing. The letter offered the Khan aid against his enemies, in particular an offer to build towns and send voevods with many service class people "to the Donets." In this manner, Russia's southern advance was diplomatically camouflaged from the Crimean Khanate, and Gazi II Giray was sent a sum of ten thousand rubles as compensation (Lashkov 1891, 32-33). When towns were built, the Crimean Khanate realized the disadvantages of its position in the region and made retaliatory steps. As the Tatars could not destroy these fortresses, they tried to use other means. In 1601 Gazi II Giray sent a secret letter to Godunov in which he reproached the Russian Tsar for building towns on the summer camps of the Tatars at the Donets. In the letter, the Khan threatened Moscow, implying Turkish intervention and warning that a further Russian southern advance could spoil their relations (Solov'ev 1994 [1901], 396). The attempt to intimidate Russia with threats of a Turkish invasion was no more than a diplomatic ruse. In spite of this bluster, the colonization of "the Field" continued.

The Tatars continually attacked Russian borderlands, but as their chief goal was plunder, they usually fled when met with resistance. Moreover they did not attempt to lay siege to stockaded towns. At least in the late sixteenth and seventeenth centuries, there were no Tatar attacks on or at- 
tempted seizures of Russian fortresses (Ishchenko 1989, 136-145). By the end of the sixteenth century, the reinforced settlements of the Russian Tsardom extended deep into the south until the confluence of the Oskol and the Severski Donets, a position rather close to Tatars' summer camps.

Russia also had considerable experience in its relations with the Polish-Lithuanian Commonwealth, which considered these territories as the part of Severskie lands won by Russia from it. The Polish government clearly never renounced its intention to regain lost territories for the Kingdom of Poland. However, in the late sixteenth century, it did not come into open conflict with Russia over this issue. Russia's southern borders were attacked only by the Ukrainian Cossacks, who were subjects of the PolishLithuanian Commonwealth. The Russian government used the Cherkasy incursions as justification for its building of fortresses "in the Field," explaining to Gazi II Giray that such actions only benefited the Tatar camps, as it drove out Cherkasy-bandits from these territories (Solov'ev 1994 [1901], 396).

One of the earliest mentions of Cherkasy "in the Field" dates back to 1571, when the Russian observation point moved from the Kolomaka River to the Ol'shanka River. This relocation happened after the Cherkasy came to the Kolomaka and attacked its sentries (Popov 1889, 13). In addition to conducting raids, which were rather common in these territories in the late sixteenth century, the Ukrainian population tried to settle on the Russian lands. The voevods of Putivl', Ryl'sk, and Novgorod-Severskii took note of such instances (Anpilogov 1967, 74). The danger of Ukrainian colonization lay in the fact that the Cherkasy who settled on the frontier lands did not pledge allegiance to the Russian Tsar and, therefore, remained subjects of the Polish-Lithuanian Commonwealth. This made the Russian government distrustful of the Cherkasy's settlement on its lands, as these migrants created potentially favorable conditions for the annexation of this territory by the Polish-Lithuanian Commonwealth. In the late sixteenth century, the Cherkasy became increasingly active. This can be explained by the fact that when the Grand Duchy of Lithuania ceded the Volyn lands and some territories at the Dnieper to the Polish-Lithuanian Commonwealth, the feudal and confessional oppression of the Ukrainian population intensified. In fact, the territory of "the Field" belonged to nobody at that time; thus Ukrainians moved there from the Polish-Lithuanian Commonwealth.

There is another point of view regarding this situation. G. N. Anpilogov considers the appearance of the Cherkasy within Russian territories as an official state policy of the Polish-Lithuanian Commonwealth (Anpilogov 1967, 19). His theory is based on information from the "stateiny spisok" (ambassadors' reports) by Pavel Volkov and Martin Sumskoi sent to Warsaw, and from identical embassy materials prepared by Afanasii Rezanov (Anpilogov 1967, 74, 85). Special attention should be paid to the Cherkasy who came for hunting, fishing, and forest beekeeping. Their colonization of lands already under development by Russian subjects created conflicts. Documents from the 1580s and 1590s that could confirm this 
view were not saved in the state department (Razriadnyi prikaz) collection. Probably these documents were destroyed in the fire of 1626 in Moscow or were lost later. Thus it is difficult to define the role of the Polish state, the heads of large territorial units, and the Polish gentry (szlachta) in the organization of the Cherkasy advance into the Russian borderlands. D. I. Bagaley has suggested that Ukrainian elders might have taken such actions irrespective of the Warsaw government (Bagalei 1886, 89). Only spontaneous actions of the Cherkasy can be confirmed with confidence, as well as the fact that the Polish administration did not impede them, as these raids were made onto the territory of a longstanding rival. Moreover the Polish government never controlled the Cherkasy in full measure.

Thus "in the Field" in the 1580s, the subjects of two hostile powers collided with one another and these collisions happened not only in the frontier zone, but also deep inside the state. We can judge the scale of this invasion from the report of leader Roman Verdevskii in the books of official orders, instructions, and directions (razryadnye knigi). On July 31, 1585, he reported that the Cherkasy destroyed his observation point on Lake Bogaty Zaton (Kuz mina 1987, 65). In a subsequent incident, Cherkasy under the command of Denis Sempski attacked peaceful villages in Briansk district (Anpilogov 1967, 80). The Cherkasy from the towns of Cherkasy and Kanev came up to Novosil' to destroy and attack the inhabitants of these borderland territories. ${ }^{13}$ In 1586 Pereslavl's Cherkasy assaulted the newlyconstructed towns of Livny and Voronezh, and also attacked stanitsas and inhabitants of different districts. ${ }^{14}$ In 1587 the voevod A. I. Khvorostinin reported on the attack of forty cherkasy from Kanev who were defeated and captured. 15

The above evidence demonstrates that in the latter half of the sixteenth century, the Dnieper-Don forest-steppe became a zone of fierce competition between the Tsardom of Russia, the Polish-Lithuanian Commonwealth, and the Crimean Khanate. The Crimean Khanate considered "the Field" as its own territory, which it used not only as the site of its summer camps, but also as a buffer zone whose existence gave an advantageous position to the state in relation to its northern neighbors. Having assessed this situation, Russia began its colonization of "the Field" in the latter half of the sixteenth century. At the same time, subjects of the Polish-Lithuanian Commonwealth-the Ukrainian Cossacks-Cherkasyalso appeared in this region. The Ukrainian colonization was spontaneous, sparked by the actions of Polish landowners, but not by the government. In contrast, Russian colonization was primarily government-led and centered on the construction of fortified towns and the stationing of armed forces in this region. This fact helps to explain why Russian colonization,

\footnotetext{
13 Rossiiskii gosudarstvennyi arkhiv drevnikh aktov [The Russian State Archive of Ancient Acts] (RGADA). Fond 79. Opis 1. Kniga 20. Listy 194 back-195.

14 RGADA. Kn. 17. L. 11-11back.

15 RGADA. Kn. 18. L. 457-458.
} 
which relied on the support of the state, had the advantage over its Ukrainian counterpart. However, the Russian government did not succeed in expelling the Ukrainians from "the Field." As a result, a peculiar compromise was reached: the Cherkasy were allowed to settle on Russian territories provided they accepted Moscow subjecthood. In the end, the Russian state succeeded in pushing back its rivals and consolidating the DnieperDon forest-steppe.

Translated from Russian by Natalia V. Grigorenko and Emily B. Baran

\section{REFERENCES}

1. Ageev, A. D. 2005. Sibir' $i$ amerikanskii Zapad: dvizhenie frontirov [Siberia and the American West: Movement of Frontiers]. Tomsk: Tomsk University Press.

2. Alekberli, M. A. 1961. Bor'ba ukrainskogo naroda protiv turetsko-Tatarskoi agressii vo vtoroi polovine XVI - pervoi polovine XVII vekov [The Fight of the Ukrainian People against the Turkish-Tatar Aggression in the 1550s through 1650s]. Saratov: Saratov University Press.

3. Anpilogov, G. N. 1967. Novye dokumenty o Rossii kontsa XVI - nachala XVII vv. [New Documents on Russia in the Late Sixteenth to Early Seventeenth Century]. Moscow: Moscow State University Press.

4. Bagalei, D. I. 1913. "Neskol'ko slov o kharaktere kolonizatsii iuzhnoi stepnoi okrainy Moskovskogo gosudarstva [A Few Words about the Character of Colonization in the Southern Steppe of the Moscow State]." In Ocherki russkoi istorii [Essays in Russian History]. Vol. 2. Khar kov: The Zil'berberg Press.

5. Bagalei, D. I. 1887. Ocherki iz istorii kolonizatsii stepnoi okrainy Moskouskogo gosudarstua [Essays on the History of Steppe Colonization of the Moscow State]. Moscow: Publishing House of the Society for History and Russian Antiquities.

6. Bagalei, D. I. 1886. "K istorii zaseleniia stepnoi okrainy Moskovskogo gosudarstva [On the History of Settlement of the Moscow State`s Steppe Edge]," Zhurnal Ministerstva narodnogo prosveshcheniia [The Ministry of Popular Education Journal] 5, 6: 87-105; 250-387.

7. Beauplan, G. L. de. 1832 [1651]. Opisanie Ukrainy [Description of Ukraine]. St. Petersburg: Tipografiia Kraiia. Original publication: Beauplan, G. L. de. 1651. Description des contres du Royayume de Pologne, contenuës depuis les confins de la Moscovie, iusques aux limites de la Transilvanie. Roüen: Jacque Cailloue.

8. Beliaev, I. D. 1846. O storozhevoi, stanichnoi i polevoi sluzhbe na Pol'skoi ukraine Moskovskogo gosudarstva do tsaria Alekseia Mikhailovicha [About the Storozhi, Stanitsy and Polevaia Duties on the Polish Ukraina of the Moscow State before Tsar Aleksei Mikhailovich]. Moscow: University Press.

9. Bromlei, Iu. V., ed. 1988. Narody mira: istoriko-etnograficheskii spravochnik [Peoples of the World: An Historical-Ethnographic Guide]. Moscow: Soviet Encyclopedia.

10. Buganov, V. I. 1980. "Razriadnye knigi kak istochnik po istorii pogranichnoi oborony Russkogo gosudarstva kontsa XV - pervoi treti XVII v. [Razriadnye Knigi as a Source on the History of Russian State Border Defenses in the Late Fifteenth to Early Seventeenth Century]." In Istochnikovedenie otechestvennoi istorii [Source Studies in National History], edited by V. I. Buganov. Moscow: Nauka publ. 
11. Bushkovitch, Paul. 1986. "The Formation of National Consciousness in Early Modern Russia." Harvard Ukrainian Studies 10: 355-376.

12. Bussow, Conrad. 1961 [1831]. Moskovskaia khronika [The Moscow Chronicle] ("Chronicon Moscoviticum, continens res a morte Joannis Basilidis Tyranni, omnium quos sol post natos homines vidit immanissimi et truculentissimi, an. Christi 1584-1612"), archeographic commentary by I. I. Smirnov. Moscow, Leningrad: The USSR Academy of Sciences Press. The manuscript was completed in 1613, first published in 1831 .

13. Cherepnin, L. V. 1960. Obrazovanie russkogo tsentralizovannogo gosudarstva $v$ XIV-XVI vekakh [The Formation of the Russian Centralized State in the $14^{\text {th }}-16^{\text {th }}$ Centuries]. Moscow: Sotsekgiz publ.

14. Dashkevich, Ia. R. 1989. "Bol'shaia granitsa Ukrainy [Big Border of Ukraine]." In Etnokontaktnye zony $v$ Evropeiskoi chasti SSSR [Ethno-Contact Zones in the European Part of the USSR]. Moscow: The Institute of Ethnography Press.

15. D'iachenko, A. G. 1998. "Drevnerusskii gorod na r. Koren' [An Ancient Russian Town on the River Koren']." In Materialy mezhdunarodnoi nauchnoprakticheskoi konferentsii "Iug Rossii v proshlom i nastoiashchem: istoriia, ekonomika, kul'tura" [Materials of the International Scholarly-Practical Conference "South of Russia: History, Economy, Culture"], 19-22. Belgorod: Belgorod State University Press.

16. Erusalimskii, K. Iu. 2011. "Pol'sko-litovskie moskovity vtoroi poloviny XVI - nachala XVII v.: sotsial'nyi sostav, kul'turnye orientiry, puti integratsii [Polish-Lithuanian Muscovites in the Late Sixteenth and Early Seventeenth Century: Social Structure, Cultural References, Paths of Integration].” In Etnokul'turnaia identichnost' narodov Ukrainy, Belorussii i Pol'shi: Mekhanizmy formirovaniia $i$ sposoby proiavleniia [The Ethno-Cultural Identity of the Peoples of Ukraine, Byelorussia and Poland: Mechanisms of Formation and Ways of Manifestation]. Moscow: Institute of Slavic Studies (Russian Academy of Sciences) Press.

17. Fal'kovich, S. M. 2011. "Istoricheskie sud'by pol'skogo naroda kak faktor formirovaniia na-tsional'nogo samosoznaniia i natsional'nogo stereotipa poliakov [The Historical Destiny of the Polish People as a Factor in Forming Polish National Self-Consciousness and National Stereotypes]." In Etnokul'turnaia identichnost' narodov Ukrainy, Belorussii $i$ Pol'shi: Mekhanizmy formirovaniia $i$ sposoby proiavleniia [The Ethno-Cultural Identity of the Peoples of Ukraine, Byelorussia and Poland: Mechanisms of Formation and Ways of Manifestation]. Moscow: Institute of Slavic Studies (Russian Academy of Sciences) Press.

18. Floria, B. N. 2002. "Otnoshenie ukrainskogo kazachestva k Rechi Pospolitoi vo vremia kazatskikh vosstanii $20-30-\mathrm{kh}$ godov XVII veka i na nachal'nom etape Narodno-osvoboditel'noi voiny [Relations between Ukrainian Cossacks and the Polish-Lithuanian Commonwealth during the Cossack Uprisings of the 1620-1630s and the early National Liberation War." Slavianovedenie [Slavic Studies] 2: 36-51.

19. Floria, B. N. 1997. "Nekotorye soobrazheniia o etnicheskom samosoznanii predkov sovremennykh belorusov [Some Thoughts about the Ethnic SelfConsciousness of Byelorussian Ancestors]." In Rus' - Litva - Belarus' [Rus ` - Lithuania-Belarus], edited by A. K. Kavko, 92-94. Moscow: Nasledie publ.

20. Floria, B. N. 1978. Russko-pol'skie otnosheniia $i$ politicheskoe razvitie Vostochnoi Evropy vo vtoroi polovine XVI - nachale XVII v. [Russian-Polish Relations and the Political Development of Eastern Europe from the 1550s through the Early Seventeenth Century]. Moscow: Nauka publ.

21. Gorizontov, L. E. 2002. "Vostochnye slaviane v XVII - XVIII vekakh: etnicheskoe razvitie i kul'turnoe vzaimodeistvie (Materialy "kruglogo stola") [Eastern 
Slavs in the Seventeenth and Eighteenth Centuries: Ethnic Development and Cultural Interaction (Roundtable Materials)]." Slavianovedenie [Slavic Studies] 2: 3-35.

22. Gumilev, L. N. 1992. Ot Rusi k Rossii: Ocherki etnicheskoi istorii [From Rus` to Russia: Essays on Ethnic History]. Moscow: Ekopros publ.

23. Gritsenko, A. A. 2010. "Vliianie politicheskikh i landshaftnykh granits na regional'nuiu identichnost' $v$ rossiisko-ukrainskom porubezh'e [The Influence of Political and Natural Borders on Regional Identity in the Russian-Ukrainian Borderlands]." 'Kandidat nauk' diss., Institute of Geography, Russian Academy of Sciences.

24. Ishchenko, S. A. 1989. Voina i voennoe delo u krymskikh tatar XVI XVIII vv. [War and Military Schooling of the Crimean Tatars in the Sixteenth to Eighteenth Centuries]." In Severnoe Prichernomor'e $i$ Povolzh'e vo vzaimootnosheniiakh Vostoka i Zapada v XII - XVII vv. [Relations between Northern Black Sea and Volga Regions and East and West in the Twelfth to Seventeenth Centuries]. Rostov-on-Don: Rostov University Press.

25. Khodarkovsky, Michael. 2002. Russia's Steppe Frontier. The Making of a Colonial Empire, 1500-1800. Bloomington; Indianapolis: Indiana University Press.

26. Khodarkovsky, Michael. 1999. "Taming the "Wild Steppe»: Muscovy's Southern Frontier, 1480-1600." Russian History / Histoire Russe 26 (3): 241-297.

27. Khoroshkevich, A. L. 1999. "Rus' i Krym posle padeniia ordynskogo iga: dinamika tributarnykh otnoshenii [Rus' and Crimea after the Collapse of the Mongol Yoke]." Otechestvennaia istoriia [National History] 2: 69-77.

28. Khoroshkevich, A. L. 2001a. Rus' i Krym: Ot soiuza $k$ protivostoianiiu [Rus 'and Crimea: From Union to Opposition]. Moscow: Editorial URSS publ.

29. Khoroshkevich, A. L. 2001b. "Kulikovskaia bitva i stanovlenie natsional'nogo samosoznaniia russkikh, ukraintsev i belorussov [The Battle of Kulikovo and the Formation of Russians, Ukrainian and Belorussian National SelfConsciousness]." In Dmitrii Donskoi i epokha vozrozhdeniia Rusi [Dmitry Donskoi and the Epoch of the Revival of Rus'], 63-78. Tula: Tul'ski poligrafist publ.

30. Kondufor, Ju. Ju. 1990. Ukraïns'ka narodnist': narysy social'noekonomychnoji y etno-politychnoi istorï [Ukrainian Nationality: Essays on Socioeconomic and Ethno-Political History]. Kyïv: Naukova dumka publ.

31. Krasnov, Iu. A. 1987. Drevnie $i$ srednevekovye pakhotnye orudiia Vostochnoi Evropy [Ancient and Medieval Plough Tools in Eastern Europe]. Moscow: Nauka publ.

32. Krylov, M. P., Gritsenko A. A. 2012. "Rossiiskaia etnokul'turnaia identichnost' $\mathrm{v}$ rossiisko-ukrainskom i rossiisko-belorusskom porubezh'e: istoricheskaia pamiat' i kul'turnye transformatsii [Russian Ethno-Cultural Identity in the Russian-Ukrainian and Russian-Belorussian Borderlands: Historical Memory and Cultural Transformation]." Labirint [Labyrinth] 2: 28-32. Accessed September 14, 2013. http://journal-labirint.com/

33. Kulish, P. A. 1888. Otpadenie Malorossii ot Pol'shi [The Disunion of Malorossiia from Poland]. Vol. I. Moscow: University Press.

34. Kuz mina, L. F., comp. 1987. Razriadnaia kniga 1475-1605 gg. Vol. 3. Part 2. Moscow: Institute of Soviet History.

35. Lashkov, F. 1891. Pamiatniki diplomaticheskikh snoshenii Krymskogo khanstva s Moskovskim gosudarstvom v XVI i XVII vv. [Records of Diplomatic Relations between the Crimean Khanate and the Moscow State in the Sixteenth and Seventeenth Centuries]. Simferopol": Tipografiia gazety "Krym."

36. Liubavskii, M. K. 1996. Obzor istorii russkoi kolonizatsii s drevneishikh vremen $i$ do XX veka [An Historical Overview of Russian Colonization from Ancient 
Times to the Twentieth Century]. Moscow: Moscow University Press. This is the first publication of the manuscript, which was written in the early twentieth century.

37. Liubavskii, M. K. 1918. Nastuplenie na step' [The Advance on the Steppe]. Moscow: Prakticheskie znaniia publ.

38. Margolin, S. L. 1948. "Oborona Russkogo gosudarstva ot Tatarskikh nabegov v kontse XVI veka [The Defense of the Russian State from Tatar Attacks in the Late Sixteenth Century]." Trudy Gosudarstvennogo istoricheskogo muzeia [Works of the State Historical Museum] 20: 3-28.

39. Mavrodin, V. V. 1978. Proiskhozhdenie russkogo naroda [The Origins of the Russian Nation]. Leningrad: Leningrad University Press.

40. Miklashevskii, I. N. 1894. K istorii khoziaistvennogo byta Moskovskogo gosudarstva [Toward a History of Household Everyday Life in the Moscow State]. Part I. Moscow: The Inokhodtsev Press.

41. Miller, A. I., ed. 1997. Rossiia - Ukraina: istoriia vzaimootnoshenii [Russia-Ukraine: A History of Relations]. Moscow: Languages of Russian Culture.

42. Mizis, Iu. A., and Kashchenko, S. G. 2011. "Problema formirovaniiu russkogo frontira na Iuge Rossii v XVI - pervoi polovine XVIII v. v otechestvennoi istoriografii [The Problem of Russian Southern Frontier Formation from 1500 to 1750 in National Historiography]." Vestnik Sankt-Peterburgskogo universiteta. Seriia 2: Istoriia [St. Petersburg University Bulletin. Series 2: History] 1: 9-16.

43. Novosel'skii, A. A. 1948. Bor'ba Moskovskogo gosudarstva s tatarami $v$ pervoi polovine XVII $v$. [The Struggle of the Moscow State with Tatars in the First Half of the Seventeenth Century]. Moscow; Leningrad: The USSR Academy of Sciences Press.

44. Padalka, L. V. 1914. Proshloe poltavskoi territorii i ee zaselenie [A History of Poltava Region and Its Settlement]. Poltava: The Poltava Learned Archeographic Commission.

45. Pashuto, V. T., Floria, B. N., and Khoroshkevich, A. L. 1982. Drevnerusskoe nasledie $i$ istoricheskie sud'by vostochnogo slavianstva [Ancient Rus` Heritage and the Historical Destinies of Eastern Slavs]. Moscow: Nauka publ.

46. Platonov, S. F. 1994 [1899]. Ocherki po istorii Smuty v Moskouskom gosudarstve XVI-XVII vv. [Essays on the Time of Trouble in the Moscow State in the Sixteenth and Seventeenth Centuries]. Moscow: Records of the Historical Thought.

47. Pokhlebkin, V. V. 1992. Vneshniaia politika Rusi, Rossii i SSSR za 1000 let $v$ imenakh, datakh $i$ faktakh [One Thousand Years of Foreign Policy of Russia, Rus, and the USSR in Names, Dates, and Facts]. Issue I. Moscow: Mezhdunarodnye otnosheniia publ.

48. Pokhlebkin, V. V. 1995. Vneshniaia politika Rusi, Rossii i SSSR za 1000 let $v$ imenakh, datakh $i$ faktakh [One Thousand Years of Foreign Policy of Russia, Rus; and the USSR in Names, Dates, and Facts]. Issue 2. Book 1. Moscow: Mezhdunarodnye otnosheniia publ.

49. Poberezhnikov, I. V. 2009. "Kanadskii i rossiiskii frontir: obshchee i osobennoe (XVI - nachalo XX v.) [Canadian and Russian Frontiers: The Common and Particular (Sixteenth to Early Twentieth Century)]." Ural'skii istoricheskii vestnik [The Urals Historical Bulletin] 2: 25-30.

50. Poberezhnikov, I. V. 2011. "Aziatskaia Rossiia: frontir, modernizatsiia [Asian Russia: Frontier and Modernization]." Izvestiia Ural'skogo federal'nogo universiteta. Seriia 2: Gumanitarnye nauki [The Urals Federal University Bulletin. Series 2: Humanitarian Sciences] 96 (4): 191-203.

51. Podgrushnyi, G. P., ed. 2010. Problemy obshchestvennoi geografii. Prigranichnye territorii: metodologicheskie podkhody $i$ opyt issledovanii [Problems of 
Social Geography. Borderland Territories: Methodological Approaches and Research]. Issue 2. Kiev: Institute of Geography, National Academy of Sciences of Ukraine.

52. Polishchuk, N. S., ed. 2000. Ukraintsy [The Ukrainians]. Moscow: Nauka publ.

53. Popov, N. A., ed. 1889. Akty Moskovskogo gosudarstva, izdannye imperatorskoiu Akademieiu nauk [Acts of the Moscow State Published by the Imperial Academy of Sciences]. Vol. I. Sankt-Petersburg: The Academy of Sciences Press.

54. Protorchina, V. M. 1948. "Zaselenie stepnoi okrainy Moskovskogo gosudarstva v kontse XVI - pervoi polovine XVII vv. [The Settlement of the Steppe Borderlands of the Moscow State from the Late Sixteenth Century to 1650]." 'Kandidat nauk' diss., Leningrad State University.

55. Rezun, D. Ia., Lamin, V. A., and Mamsik T. S. 2002. Frontir $v$ istorii Sibiri $i$ Severnoi Ameriki $v$ XVII - XX vv.: obshchee $i$ osobennoe [The Frontier in the History of Siberia and North America in the Seventeenth to Twentieth Centuries; The Common and Particular]. Novosibirsk: RIPEL plius publ.

56. Rezun, D. Ia., and Shilovskii, M. V. 2005. Sibir', konets XVI-nachalo XX veka: frontir $v$ kontekste etnosotsial'nykh $i$ etnokul'turnykh protsessov [Siberia in the Late Sixteenth to Early Twentieth Century: The Frontier in the Context of Ethno-Social and Ethno-Cultural Processes]. Novosibirsk: Sova publ.

57. Rusyna, O. V. 1998. Ukrai'na pid tataramy i lytvoju [Ukraine under the Tatars and Lithuania]. Kyi'v: Al'ternativy publ.

58. Sakharov, A. N., ed. 1999. Istoriia vneshnei politiki Rossii. Konets XVXVII veka [A History of Russia's Foreign Policy from the End of the Fifteenth to the Seventeenth Century]. Moscow: Mezhdunarodnye otnosheniia publ.

59. Shaw, D. J. B. 1983. "Southern Frontier of Moscow 1550-1770." Studies in Russian Historical Geography 1: 117-142.

60. Skrynnikov, R. G. 1997. Istoriia Rossiiskaia. IXX-VII vv. [Russian History. Ninth to Seventeenth Century]. Moscow: Ves`mir publ.

61. Smolij, V. A., V. S. Stepanov. 1999. Ukrai'ns'ka nacional'na revoljucija XVII st. [The Ukrainian National Revolution of the Seventeenth Century]. Kyi'v: Institute of Archeography, National Academy of Sciences of Ukraine.

62. Solodkin, Ia. G. 1999. "Ukraintsy v Sibiri kontsa XVI - nachala XVII vv. [Ukrainians in Siberia in the Late Sixteenth to Early Seventeenth Centuries]." Sotsiokul'turnaia dinamika Khanty-Mansiiskogo avtonomnogo okruga segodnia $i v$ perspektive XXI veka [Socio-Cultural Dynamics of the Khanty-Mansi Autonomious District at Present and in Twenty-First Century Perspective], 37-41. Surgut: Surgut State University Press.

publ.

63. Solov'ev, S. M. 1993 [1901]. Sochineniia [Oeuvre]. Vol. V. Moscow: Golos

64. Solov'ev, S. M. 1994 [1901]. Sochineniia [Oeuvre]. Vol. VIII. Moscow: Golos publ.

65. Stanislavskii, A. L. 1990. Grazhdanskaia voina v Rossii XVII v. [Civil War in Russia in the Seventeenth Century]. Moscow: Mysl' publ.

66. Sysyn, Frank E. 1986a. "Concept of Nationhood in Ukrainian History Writing, 1620-1690.” Harvard Ukrainian Studies 10: 393-423.

67. Sysyn, Frank E. 1986b. "Recent Western Works on the Ukrainian Cossacks." Slavonic and East European Review 64 (1): 100-116.

68. Sysyn, Frank E. 1985. Between Poland and the Ukraine. Cambridge, Mass.: Harvard University Press.

69. Tikhomirov, M. N. 1962. Rossiia $v$ XVI stoletii [Russia in the Sixteenth Century]. Moscow: Nauka publ. 
70. Tropin, N. A. 1999. Eletskaia zemlia $v$ XII - XV vv. [The Elets Land in the $12^{\text {th }}-15^{\text {th }}$ Cent.]. Elets: Elets State Pedagogical Institute Press.

71. Vinnikov, A. Z., and Kudriavtseva, E. Iu. 1998. "Gorodishche Kholki na iugo-vostochnoi okraine Drevnerusskogo gosudarstva [Gorodishche Kholki in the Southeastern Edge of the Ancient Rus' State'." Voprosy istorii slavian. Arkheologiia. Etnografiia [Questions in the History of the Slavs. Archeology. Ethnography] 12: 50-71.

72. Vodarskii, Ia. E. 1973. Naselenie Rossii za 400 let (XVI-nachalo XX v.) [The Russian Population in Four Hundred Years (the Sixteenth to Early Twentieth Century)]. Moscow: Prosveshchenie publ.

73. Vorob'eva, T. D. 2012. "Istoriia Kamchatki s pozitsii metodologii frontira [A History of Kamchatka using Frontier Methodology." In Piatye mezhdunarodnye istoricheskie $i$ Sviato-Innokent'evskie chteniia: materially [Materials of the Fifth International Historical and St. Innokentii Presentations], 101-104. Petropavlovsk-Kamchatskii. Accessed February 10, 2014. http://www.kamlib.ru/resourses/vorobieva5.htm

74. Zaborovskii, L. V. 1981. Rossiia, Rech' Pospolitaia i Shvetsiia $v$ seredine XVII v. [Russia, the Polish-Lithuanian Commonwealth, and Sweden in the MidSeventeenth Century]. Moscow: Mysl` publ.

75. Zagorovskii, V. P. 1991. Istoriia vkhozhdeniia Tsentral'nogo Chernozem'ia $v$ sostav Rossiiskogo gosudarstva $v$ XVI veke [A History of Incorporation of the Central Black Earth Region into the Russian State in the Sixteenth Century]. Voronezh: Voronezh State University Press.

76. Zagorovskii, V. P. 1972. "Nekotorye voprosy rannei narodnoi kolonizatsii pol'skoi okrainy Rossii [Some Questions of the Early People`s Colonization of the Field's Borderland of Russia]." In Ezhegodnik po agrarnoi istorii Vostochnoi Evropy za 1698 g. [Yearbook of Agrarian History of Eastern Europe in 1698]. Leningrad: Nauka publ.

77. Zamiatina, N. Iu. 1998. "Zona osvoeniia (frontir) i ee obraz v amerikanskoi i russkoi kul'turakh [The Zone of Settlement (Frontier) and Its Image in American and Russian Cultures]." Obshchestvennye nauki i sovremennost' [Social Sciences and the Contemporaneity] 5: 75-78.

78. Zhukov, D. S., V. V. Kanishchev, and S. K. Liamin. 2012. "Frontir i fraktal: podkhody $\mathrm{k}$ komp'iuternomu modelirovaniiu dinamiki rossiiskogo frontira [Frontier and Fractal: Approaches to the Computer Modelling of Russian Frontier Dynamics]." Fractal Simulation 2: 26-35.

79. Zimin, A. A. 1972. Rossiia na poroge novogo vremeni [Russia at the Turn of the Modern Era]. Moscow: Mysl` publ. 